\title{
PELAKSANAAN PENJADUALAN SEMULA PEMBIAYAAN MIKRO MURĀBAHAH DI BANK SYARIAH MANDIRI CAWANGAN DUMAI, INDONESIA
}

\section{Implementation of Rescheduling in Murābahah Micro Financing At Bank Syariah Mandiri Branch Dumai, Indonesia}

\author{
Ahmad Maulidizen ${ }^{1}$ \\ Joni Tamkin Borhan²
}

\begin{abstract}
This research is an analysis of the rescheduling of muräbahah micro financing in Bank Syariah Mandiri Branch Dumai, Indonesia. There are many Shariah banks in Indonesia experiencing problems due to unpaid financing and can lower bank performance. Therefore, the bank is implementing the rescheduling of muräbahah micro financing to avoid exceeding the level set by Bank Indonesia of 5\%. This research was conducted to analyze in depth about the rescheduling of murābahah micro financing implemented by Bank Syariah Mandiri Branch Dumai, Indonesia. This research uses data collection method by observation, interview and library data which then analyzed by
\end{abstract}

Ph.D Candidate, Department of Shariah and Economics, Academy of Islamic Studies, University of Malaya, 50603 Kuala Lumpur, ahmadzen682@gmail.com

2 Professor, Department of Shariah and Economics, Academy of Islamic Studies, University of Malaya, 50603 Kuala Lumpur, joni@um.edu.my 
using inductive, deductive and comparative method. The result of this research is in the implementation of rescheduling the murābahah micro financing, there are three conditions, namely 1) not increasing the amount of remaining debt, 2) the costs in the rescheduling process are the actual costs, and 3) the additional payment time must be based on the agreement of both parties. From these conditions, the bank only does two, namely not increasing the amount of the remaining debt and adding payment time, while the bank is still wearing the customer with the rescheduling or penalty fees that make it difficult for the customer. Because of that, there are three suggestions from the researcher that is to provide a wide payment time, reschedule without the costs charged to the customer (penalty) except the actual costs such as administrative costs and conversion of murābahah financing contract into a qard financing contract.

Keywords: rescheduling, murābahah financing, Bank Syariah Mandiri Branch Dumai

\section{PENDAHULUAN}

Islam merupakan panduan hidup manusia dan ianya diciptakan untuk membawa manusia kepada kebahagiaan dunia dan akhirat (falāh) sebagaimana termaktub dalam al-Quran dan al-Sunnah. Islam juga mengatur kehidupan manusia dalam pelbagai aspek, ${ }^{3}$ sama ada 'ubūdīyyah atau mu 'àmalah. ${ }^{4}$ Selain prinsipprinsip di atas, hukum Islam mempunyai moral ekonomi Islam yang dikenali

3 Ajaran al-Quran yang bersifat global ini selari dengan fitrah manusia yang bersifat dinamis mengikuti perubahan zaman. Apabila majoriti ayat-ayat al-Quran bersifat mutlak dan terperinci, manusia akan terikat, seterusnya akan menghambat perkembangan masyarakat. Inilah hikmah daripada keumuman ayat-ayat tersebut. Lihat Harun Nasution, Akal dan Wahyu dalam Islam (Jakarta: UI Press, 1986), 29. Lihat juga Adiwarman Karim, Sejarah Pemikiran Ekonomi Islam (Jakarta: PT. Raja Grafindo Persada, 2004), 5; J. Michael Taylor, 'Islamic Banking the Feasibility of Establishing an Islamic Bank in the United State,' American Business Law Journal, 40 (2003), 387.

4 Nima Mersadi Tabari, 'Islamic Finance and the Modern World: The Legal Principles Governing Islamic Finance in International Trade,' Journal Company Law, 31/8 (2010): 249-254. 
dengan "golden five", iaitu keadilan, kebebasan, persamaan, penyertaan dan kebertanggungjawaban. ${ }^{5}$

Falsafah pembiayaan Bank Syariah wajib memenuhi aspek Syariah dan aspek ekonomi. ${ }^{6}$ Salah satu bentuk pembiayaan Bank Syariah adalah murābahah, iaitu bank membiayai pembelian sesebuah barang atau aset atas nama pelanggan dan menambahkan mark-up (kenaikan) sebelum menjual kembali kepada pelanggan, kemudian pembayaran dilakukan selama tempoh pada masa tertentu atau secara ansuran. Dalam memberikan pembiayaan kepada pelanggan, bank mesti melakukan analisis agar pembiayaan tidak mengalami masalah. Oleh itu, bank hendaklah melaksanakan sistem kawal selia bagi mengelakkan berlaku pembiayaan tidak berbayar yang boleh menurunkan prestasi bank. Di antara faktor kelemahan bank adalah segi kajian, faktor keculasan pelanggan, dan faktor luaran dan dalaman (perundangan kerajaan, risiko perniagaan atau bencana/musibah). ${ }^{7}$ Bank Syariah memerlukan langkah penjadualan semula bagi mengatasi pembiayaan tidak berbayar agar tidak melampaui kadar ketetapan Bank Indonesia sebesar 5\%. Oleh kerana itu, kajian ini bertujuan menganalisis penjadualan semula pembiayaan mikro murābaḥah di Bank Syariah Mandiri Cawangan Dumai Indonesia.

\section{METODOLOGI KAJIAN}

Kajian berasaskan kes yang berlaku di Bank Syariah Mandiri Cawangan Dumai. Kajian ini adalah kajian lapangan (field research) yang memfokuskan kepada pelaksanaan penjadualan semula pembiayaan murābahah bagi pembiayaan usaha mikro, faktor yang menjadi asas Bank Syariah Mandiri Cawangan Dumai melaksanakan penjadualan semula pembiayaan mikro murābahah dan mengenal pasti pelaksanaan sama ada sesuai atau tidak. Kajian ini dijalankan di Bank Syariah Mandiri Cawangan Dumai, pemilihan ini dibuat kerana bank ini merupakan bank Syariah yang mempunyai aset tertinggi di Indonesia dan merekodkan kadar kegagalan tertinggi dalam pembayaran. Penulis menggunakan metod pengumpulan data secara dokumentasi, temu bual

5 Muhammad Fadel, 'Shari'a: Islamic Law in Contemporary Contex,' Journal of Law and Religion, 24 (2009): 102; Faisal, 'Rektrukturiasi Pembiayaan Murābahah dalam Mendukung Manajemen Resiko Sebagai Implementasi Prudential Principle Pada Bank Syariah di Indonesia,' Jurnal Dinamika Hukum, 11/3 (2011), 463-471.

6 Veithzal Rivai, Islamic Banking: Ekonomi Islam Bukan Opsi Tetapi Solusi (Jakarta: Bumi Aksara, 2010), 680; Muhammad, Manajemen Pembiayaan Bank Syariah (Yogyakarta: Unit Penerbit dan Percetakan AMP YKPN, 2005), 17.

7 AS. Mahmoeddin, 100 Penyebab Kredit Macet (Jakarta: Pustaka Sinar Harapan, 1994), 14-15. 
yang dilakukan secara persampelan bertujuan, iaitu menemu bual individuindividu tertentu terutama yang berautoriti di dalam satu-satu bidang dalam penelitian ini, antaranya; Ketua Bank Syariah Mandiri Cawangan Dumai, iaitu Mohmmad Fadjar, Bahagian Pemasaran Bank Syariah Mandiri Cawangan Dumai, iaitu M. Restu al-Fahmi dan Arfan Maulana, dan Dewan Pengawas Syariah Bank Syariah Mandiri Cawangan Dumai. Manakala kaedah analisis data ini terbahagi kepada tiga bahagian iaitu induktif, deduktif dan komparatif.

\section{PENGERTIAN MURĀBAHAH MENURUT FIQH}

Perkataan murābaḥah berasal daripada kata kerja rābaḥa, yurābihu, murābaḩatan. Kata kerja asalnya adalah dari fi'il thulāthi iaitu rabaha. Dalam kamus Lisān al- 'Arabī, perkataan al-ribhu, al-rabaḥu dan al-rabbahu membawa maksud yang sama iaitu pertambahan atau pertumbuhan dalam perniagaan. ${ }^{8}$ Manakala Ibn al-'Arabi pula menyatakan perkataan al-ribhu dan al-rabahu bermakna keuntungan dalam perniagaan. Kombinasi takrifan tersebut membawa kepada pengertian al-ribh sebagai keuntungan daripada pusingan modal sama ada ianya melalui pekerjaan, urusniaga dan sebarang transaksi yang dilakukan secara individu mahupun kolektif.' Sedangkan murābaḥah adalah kata yang berasal daripada kata kerja rābaḥa yang bermaksud saling memberi keuntungan antara pembeli dan penjual iaitu memperoleh barangan dan memiliki sesuatu barangan. ${ }^{10}$

Murābahah harus digunakan sebagai kontrak pendasar bagi produk pembiayaan. ${ }^{11}$ Walaupun, tiada ayat al-Quran dan hadis yang menyebut secara langsung keharusan kontrak murābaḥah, tetapi keharusan tersebut

8 Abū al-Faḍl Jamāl al-Dīn Muhammad Ibn Mukarram Ibn Manẓūr, Lisān al- 'Arab, vol. 4 (Qāhirah: al-Dār al-Mișriyyah li al-Ta'līf wa al-Tarjamah, 1954), 268; alFīrūzābādī, al-Qāmūs al-Muḥ̣̂t, vol. 1 (Bayrūt: Dār al-Fikr, 1983), 221; Ascarya, Akad dan Produk Bank Syariah (Jakarta: Rajawali Press, 2011), 81-82.

9 Nur Kholis, 'Murābahah sebagai Instrumen Pembiayaan Islam: Konsep dan Pelaksanaannya di Baitul Mal Wattamwil (BMT) Yogyakarta,' (Disertasi Sarjana, Jabatan Syariah dan Ekonomi, Akademi Pengajian Islam, Universiti Malaya, Kuala Lumpur, 2006), 34.

10 Nor 'Azzah Kamri \& Fadhilah Mansor, 'Aplikasi Konsep al-Murābaḥah dalam Penawaran Instrumen di Institusi Perbankan Islam di Malaysia,' Prosiding Seminar Kewangan Islam (Kuala Lumpur: Akademi Pengajian Islam Universiti Malaya, 2002), 126. Lihat pula Nur Kholis, "Murābahah Sebagai Instrumen Perbankan Islam: Konsep dan Pelaksanaanya di Baitul Mal Wattamwil (BMT) Yogyakarta Indonesia”, 38.

11 Imām 'Alāw al-Dīn Abī Abū Bakr Ibn Mas'ūd al-Kāsānī, Badā' $i$ ' al-Sanā' $i$ ‘ fì Tartīb al-Sharā'i', vol. 5 (Bayrūt: Maṭba'ah al-'Āṣimah, t.t.), 220. 
difahami melalui keutamaan ayat berhubung keharusan jual beli, pengambilan keuntungan, kerugian dan perniagaan. ${ }^{12}$ Walaupun para fuqaha memberi pelbagai takrifan murābaḥah, namun kesemuanya membawa maksud yang sama. Menurut Ibn al-Humām, murābaḥah adalah suatu akad penyerahan barangan perniagaan yang dimiliki oleh seseorang, berdasarkan kos harga asal pada akad yang pertama, serta menambah keuntungan, dengan memaklumkannya kepada pembeli. ${ }^{13}$ Keuntungan yang dipersetujui boleh sama ada ditentukan dalam bentuk jumlah wang tertentu atau dalam bentuk peratusan tertentu daripada nisbah harga pembeliannya, misalnya $10 \%$ atau $20 \% .^{14}$

Ibn Qudāmah memberikan definisi sebagai suatu bentuk urusniaga yang menjual suatu barangan dengan harga modal serta menambah keuntungan yang diketahui. ${ }^{15}$ Al-Imām Mālik turut menjelaskan bahawa murābaḥah iaitu apabila ia menjual sesuatu dengan mengambil keuntungan satu dirham bagi setiap dirham modal yang dikeluarkannya atau setengah dirham bagi setiap dirham yang dikeluarkannya, atau sebelas dirham bagi setiap sepuluh dirham modal yang dikeluarkannya, sama ada untungnya sedikit dari modal atau untungnya lebih banyak daripada modal, bergantung di atas persetujuan kedua belah pihak. ${ }^{16}$ Al-Imām Mālik mendasarkan keabsahan murābaḥah dengan 'amalu ahli al-Madinah "Ada konsensus pendapat di sini (Madinah) mengenai hukum orang yang membeli baju di sebuah kota, dan mengembalikannya ke kota lain untuk menjualnya berdasarkan suatu kesepakatan terhadap keuntungan". Al-

12 Joni Tamkin Borhan, 'Bay' al-Murābahah in Islamic Commercial Law,' Jurnal Syariah, 6 (1998): 53; Abdullah Saeed, Islamic Banking and Interest: A Study of the Prohibition of Riba and Its Contemporary (Leiden: E.J. Brill, 1996), 76.

13 Al-Imām Kamāl al-Dīn 'Abd al-Rāḥid al-Sirāsi Ibn al-Ḥumām, Sharh Fath alQadīr, vol. 5 (Bayrūt: Dār al-Kutub al-'Ilmiyyah, 1970), 252.

14 Al-Sharbīnī Muhammad al-Khațīb, Mughnī al-Muhtājj, vol. 2 (Qāhirah: Sharīkah Maktabah wa Maṭba'ah al-Mușțafā al-Bābī al-Ḥalābī wa Awlādih, 1958), 77; Dewi Nurul Musjtari, Penyelesaian Sengketa Operasional Bank Syariah (Yogyakarta: Nuha Medika, 2000), 55; Muhammad, Sistem dan Prosedur Operasional Bank Syariah (Yogyakarta: UII Press, 2000), 22.

15 'Abd Allāh Ibn Aḥmad al-Maqdisī Ibn Qudāmah, al-Mughn̄̄ wa al-Sharh alKabīr, vol. 4 (Bayrūt: Dār al-Kutub al-'Arabī, 1972), 102; Syams al-Dīn alSyaikh Muhammadal-Dasūqī (t.t.), Hasyiyah al-Dasūqū 'alā al-Syarh al-Kabīr, juz 4 (Bayrūt: Dār al-Fikr), 159; Ahmad Maulidizen \& Mohammad Taqiuddin Mohamad, 'Murābaḥah Sebagai Instrumen Pembiayaan dalam Keuangan Islam Modern,' Jurnal Ijtimiyyah, 11/1 (2018): 303-332.

16 'Abd al-Salām Ibn Sa'īd Habīb al-Tanūkhī Șaḥnūn, al-Mudawwanah al-Kubrā, vol. 3 (Bayrūt: Dār al-Șadīr, t.t.), 325. 
Imām al-Shāfi' $\overline{1}$, menerima keabsahan murābaḥah. Beliau menyatakan: "Jika seseorang menunjukkan komoditi kepada seseorang dan mengatakan, "Kamu beli untukku, aku akan memberimu keuntungan begini, begini”, kemudian orang itu membelinya, maka transaksi itu sah". ${ }^{17}$ Al-Imām al-Nawawī, salah satu tokoh dalam mazhab Shāfi 'ī menyatakan murābaḥah sah menurut hukum tanpa ada bantahan. ${ }^{18}$

Ibn Rushd mendefinisikan murābahah sebagai jual beli barangan pada harga modal dengan tambahan keuntungan yang disepakati. ${ }^{19}$ Ulama' Hanafī membenarkannya berdasarkan kondisi penting bagi keabsahan penjualan di dalamnya, dan juga kerana manusia memerlukannya. ${ }^{20}$ Dengan demikian murābahah merupakan penjualan barangan pada harga tertentu yang meliputi harga belian dan margin keuntungan dan harga tersebut disepakati oleh keduakedua pihak berkontrak. ${ }^{21}$ Dengan menggunakan kaedah murābah̆ah, pemilik barangan (pihak bank) membuat perjanjian jual beli dengan pelanggan. Dalam hal ini pelanggan sebagai rakan kongsi memohon daripada pihak bank untuk membeli sesuatu aset untuknya. Pihak bank akan membeli aset yang dikehendaki dan akan menjual kepada pelanggan dengan suatu tingkat harga yang meliputi kos awal beserta tambahan untung tertakluk kepada persetujuan kedua-kedua belah pihak. ${ }^{22}$ Pelanggan pula akan membayar balik secara ansuran mengikut tempoh tertentu yang dipersetujui bersama tanpa sebarang faedah atau bunga yang dikenakan ke atas hutang tersebut. Oleh itu, dapat difahami bahawa mekanisme murābahah yang berlaku sekarang adalah

17 Muḥammad bin Idrīs al-Shāfi`î, al-Umm (Qāhirah: Dār al-Sha‘b, 1968), 33.

18 Abū Zakariyyā Muhyy al-Dīn bin Sharf al-Nawawī, Raw ḍh al-Tāilibīn (al-Maktab al-Islāmī li al-Tabā' wa al-Nashr, t.t.), 526.

19 Muḥammad Ibn Aḥmad Ibn Muhammad Ibn Rushd, Bidāyah al-Mujtahid wa Nihāyah al-Muqtașid, vol. 2 (Bayrūt: Dār al-Qalam, 1988), 216.

20 Abdullah Saeed, Islamic Banking and Interest: A Study of the Prohibition of Riba and Its Contemporary Interpretation, 77. Lihat pula Nur Kholis, "Murābahah Sebagai Instrumen Perbankan Islam: Konsep dan Pelaksanaanya di Baitul Mal Wattamwil (BMT) Yogyakarta Indonesia", 31.

21 Muhammad Taqi Usmani, An Introduction to Islamic Finance (London: Kluwer Law International, 2002), 41; Muḥammad Șalāh Muḥammad al-Șāwī, Musykillah al-Istithmār fì al-Bunūk al-Islāmiyyah (Jeddah: Dār al-Mujtama', 1990), 198.

22 Joni Tamkin Borhan, 'Falsafah Ekonomi dan Instrumen $M u$ 'āmalah dalam Amalan Perbankan Islam di Malaysia,' Jurnal Usuluddin, 13 (2001): 131; Muhammad Sholihuddin, Kamus Istilah Ekonomi, Keuangan dan Bisnis Syariah (Jakarta: PT. Gramedia Pustaka Utama, 2011), 111; Adrian Sutedi, Perbankan Syariah Tinjauan dan Beberapa Segi Hukum (Bogor: Ghalia Indonesia, 2009), 95. 
merupakan skim perniagaan barangan antara kedua belah pihak yang mengikut persetujuan pada harga yang merangkum harga barangan dan keuntungan. ${ }^{23}$

\section{PELAKSANAAN PEMBIAYAAN MIKRO MUR̄̄BAHAH DI BANK SYARIAH MANDIRI CAWANGAN DUMAI}

\section{Pengertian}

Pembiayaan Mikro Murābaḥah iaitu pembiayaan bersifat produktif kepada individu atau institusi perniagaan dengan pembiayaan maksimum sebanyak Rp. 100 juta. Pembiayaan jenis ini juga boleh diberikan kepada individu dengan kadar maksimum Rp. 50 juta. ${ }^{24}$

\section{Jenis Pembiayaan Mikro}

Jenis pembiayaan mikro di Bank Syariah Mandiri Cawangan Dumai boleh dibahagi kepada tiga, iaitu (1) Pembiayaan Perniagaan Mikro Tunas, iaitu pembiayaan perniagaan mikro kepada individu atau institusi dengan jumlah pembiayaan keseluruhan minimum Rp 2 juta dan maksimum Rp 10 juta. (2) Pembiayaan Perniagaan Mikro Madya, iaitu pembiayaan perniagaan mikro kepada individu atau institusi dengan jumlah pembiayaan keseluruhan minimum Rp 10 juta dan maksimum Rp. 50 juta, dan (3) Pembiayaan Perniagaan Mikro Utama, iaitu pembiayaan perniagaan mikro dari bank kepada individu atau institusi perniagaan dengan jumlah pembiayaan keseluruhan minimum $\mathrm{Rp} 50$ juta dan maksimum Rp 100 juta.

23 Muḥammad Sulaymān al-Asyqar, "bay" al-murābahah kama Tajrīhi al-Bunūk al-Islāmiyyah", dalam Muhammad Sulaymān al-Asyqar et al., Buhūth Fiqhiyyah fì Qaḍāya Iqtiṣādiyyah Mu'āṣirah, vol. 1 ('Ammān: Dār al-Nafā'is, 1998), 71; Sudin Haron, Prinsip dan Operasi Perbankan Islam (Kuala Lumpur: Berita Publishing Sdn. Bhd., 1996), 318; Muhammad Syafi'i Antonio, Bank Islam dari Teori ke Praktek (Jakarta: Gema Insani Press, 2011), 101; Muḥammad Ṣalāḥ Muḥammad al-Șāwī, Musykillah al-Istithmār fì al-Bunūk al-Islāmiyyah, 199-200; Sami Hamoud, Islamic Banking (London: Arabian Information Ltd., 1985), 237; Adiwarman Karim, Bank Islam (Analisis Fiqih dan Kewangan) (Jakarta: PT. Raja Grafindo Persada, 2004), 113; Burhanuddin S., Aspek Hukum Lembaga Kewangan Syariah (Yogyakarta: Graha Ilmu, 2010), 73.

24 Dokumentasi Bank Syariah Mandiri; Arfan Maulana (Bahagian Pemasaran, Bank Syariah Mandiri, Cawangan Dumai, Indonesia), dalam temu bual beliau bersama penulis pada 20 Disember 2015. 


\section{SIKAP DAN TINDAKAN PENGERUSI BANK SYARIAH MANDIRI CAWANGAN DUMAI TERHADAP KEGAGALAN PEMBAYARAN ANSURAN OLEH PELANGGAN}

Kegagalan pembayaran sama ada akibat keingkaran membayar atau penangguhan pembayaran sememangnya berlaku di institusi kewangan Islam. ${ }^{25}$ Keingkaran dan penangguhan ini disebabkan sikap mudah para pelanggan dalam menjelaskan ansuran tepat pada masanya di samping itu terdapat segelintir pelanggan yang sememangnya menghadapi masalah kesempitan wang sehingga gagal membuat bayaran ansuran sebagaimana yang dijanjikan dalam kontrak yang dimaterai. ${ }^{26}$

Dalam sistem perbankan Islam mahupun konvensional, penyebab peningkatan kadar pembiayaan tak berbayar kerana keingkaran pelanggan. ${ }^{27}$ Apa yang difahami ialah murābahah merupakan kontrak yang merekod kegagalan pembayaran paling tinggi ${ }^{28}$ Dalam isu terjadi kegagalan pembayaran ansuran oleh pelanggan, pada asasnya pihak pengerusi bank mempunyai sikap dan cara iaitu dengan cara kekeluargaan, memberikan tempoh selewat-lewatnya tiga hari dari tarikh yang telah disepakati sebagai satu toleransi, mencari jalan penyelesaian alternatif dengan mencari maklumat untuk menyelesaikan kewajipan. ${ }^{29}$ Jika pendekatan tersebut tidak berjaya, langkah terakhir adalah menarik kembali barangan yang telah dibeli oleh pihak pelanggan berkenaan dengan dana dari institusi, seterusnya barangan itu dimanfaatkan/dijual secara bersama-sama untuk mendapatkan wang tunai. Hasil wang tunai tersebut digunapakai untuk menyelesaikan kewajipan pelanggan kepada pihak bank.

25 Muhammad Taqi Usmani, An Introduction to Islamic Finance, 55.

26 Nor 'Azzah Kamri \& Fadhilah Mansor, 'Aplikasi Konsep al-Murābaḥah dalam Penawaran Instrumen di Institusi Perbankan Islam di Malaysia,' Prosiding Seminar Kewangan Islam (Kuala Lumpur: Akademi Pengajian Islam Universiti Malaya, 2002), 138; Ahmad Maulidizen \& Joni Tamkin Borhan, 'Aplikasi Pembiayaan Modal Kerja Murābaḥah bi al-Wakālah: Studi Kasus Pada Bank Muamalat Indonesia Cabang Sungkono Surabaya,' Jurnal Ilmiah Islam Futura, 16/1 (2016): 91-109.

27 Pembayaran tidak terbayar iaitu istilah lain daripada NPF (Non Performing Financing) untuk bank Islam dan NPL (Non Performing Loan) untuk bank konvensional.

28 Secara realitinya perbankan Syariah lebih banyak mengamalkan instrumen murābahah yang kadarnya mencapai $82 \%$ dari keseluruhan pembiayaan yang dilakukan. Otoriti Perkhidmatan Bank Indonesia, 2018.

29 M. Restu al-Fahmi (Bahagian Pemasaran Bank Syariah Mandiri, Cawangan Dumai), dalam temu bual beliau bersama penulis pada 10 Januari 2015. 
Bakinya diberikan kepada pelanggan berkenaan. Pihak bank tidak mengenakan sebarang denda kepada pelanggan. ${ }^{30}$

\section{PELAKSANAAN PENJADUALAN SEMULA PEMBIAYAAN MIKRO $M U R \bar{A} B A H A H$ DI BANK SYARIAH MANDIRI CAWANGAN DUMAI}

\section{a) Pengertian}

Penjadualan semula pembiayaan merupakan cara yang dilaksanakan bank terhadap pembiayaan yang masih mempunyai keupayaan perniagaan, tenaga, kemampuan membayar serta tekad baik dan tujuan bagi meminimumkan kebarangkalian kerugian dan menyelamatkan kembali pembiayaan yang diberikan. Terdapat dua cara bagi mengatasi pembiayaan bermasalah di Bank Syariah Mandiri Cawangan Dumai, iaitu penstrukturan pembiayaan dan penjualan barang cagaran. Penstrukturan yang diamalkan bank iaitu penjadualan semula yang dilakukan dengan cara menukar beberapa atau seluruh penetapan yang ada dalam akad pembiayaan, sedangkan penjualan cagaran iaitu menjual barang yang dijadikan cagaran oleh pelanggan yang berdasarkan pada surat kuasa menjual cagaran dari pelanggan yang kemudian hasil penjualannya digunakan untuk menjelaskan hutangnya kepada bank. ${ }^{31}$

\section{b) Ketentuan Penjadualan Semula}

Kriteria yang dipertimbangkan dalam melakukan penjadualan semula pembiayaan ialah meneliti aspek kemampuan pelanggan dalam membayar dan perkembangan perniagaan cukup baik dan kemampuan pelanggan selepas penjadualan semula. Pelaksanaan penjadualan semula didasarkan kepada surat permohonan dari pelanggan dan disokong nota analisis dan bukti-bukti yang menyokong (laporan kewangan pelanggan, kontrak baru yang diperolehi oleh pelanggan dan sumber pembayaran lain yang jelas. Pembiayaan yang akan dilakukan penjadualan semula dianalisis berdasarkan faktor yang menjadi pertimbangan iaitu perniagaan pelanggan mempunyai prospek yang baik dan

30 M. Restu al-Fahmi (Bahagian Pemasaran Bank Syariah Mandiri, Cawangan Dumai), dalam temu bual beliau bersama penulis pada 10 Januari 2015.

31 M. Restu al-Fahmi (Bahagian Pemasaran Bank Syariah Mandiri, Cawangan Dumai), dalam temu bual beliau bersama penulis pada 10 Januari 2015; Muhammad Sholihuddin, Kamus Istilah Ekonomi, Keuangan dan Bisnis Syariah, 150 . 
berkemampuan membayar kewajiban berasaskan unjuran aliran wang bagi pelanggan pembiayaan produktif dan konsumtif. ${ }^{32}$

\section{c) Frekuensi Penjadualan Semula}

Penjadualan semula dilaksanakan sebanyak 3 kali untuk pembiayaan mikro murābahah. ${ }^{33}$ Contoh: Pelanggan A telah memohon pembiayaan dari Bank Syariah Mandiri Cawangan Dumai dengan akad pembiayaan mikro murābahah. Dalam tempoh masa yang telah ditetapkan, pelanggan mempunyai peluang untuk meminta penjadualan semula atas pembiayaan tersebut sebanyak 3 kali.

\section{d) Surat Permohonan dan Analisa Penjadualan Semula}

Penjadualan semula harus berdasarkan surat permohonan dari pelanggan. Surat permohonan tersebut boleh diyakini kebenaran dan disahkan oleh bahagian pembiayaan, pelanggan membubuhkan tandatangan seluruh dokumen sebelum analisis penjadualan semula diproses. Kemudian hasil analisis penjadualan semula dimasukkan dalam Nota Analisis Penstrukturan Pembiayaan. ${ }^{34}$

\section{e) Jawatankuasa Penjadualan Semula}

Jawatankuasa Penjadualan Semula; ketetapan jawatankuasa penjadualan semula merujuk kepada peraturan pembiayaan tentang organisasi dan jawatankuasa pembiayaan. Dalam proses penjadualan semula terdapat komite pemutus pembiayaan, yang bertugas menguruskan penjadualan semula pembiayaan. Pelanggan penjadualan semula dalam kategori kualiti lancar dan dalam perhatian khusus akan ditadbir oleh Unit Bisnes Pengelolaan Pembiayaan. Manakala pelanggan dalam kategori kualiti kurang lancar dan diragui ditetapkan oleh Unit Perniagaan.

32 M. Restu al-Fahmi (Bahagian Pemasaran Bank Syariah Mandiri, Cawangan Dumai), dalam temu bual beliau bersama penulis pada 10 Januari 2015.

33 M. Restu al-Fahmi (Bahagian Pemasaran Bank Syariah Mandiri, Cawangan Dumai), dalam temu bual beliau bersama penulis pada 10 Januari 2015.

34 M. Restu al-Fahmi (Bahagian Pemasaran Bank Syariah Mandiri, Cawangan Dumai), dalam temu bual beliau bersama penulis pada 10 Januari 2015. 


\section{f) Tata Cara Penjadualan Semula}

Penjadualan semula dilakukan dengan memanjangkan tempoh masa pembiayaan tanpa penambahan baki hutang pelanggan. Penjadualan semula pembiayaan itu boleh dilaksanakan atas permohonan secara bertulis daripada pelanggan. Merujuk kepada permohonan bertulis tersebut kepada pihak bank, maka hendaklah melalui beberapa peringkat sepertimana berikut:

Carta 1: Pelaksanaan Penjadualan Semula Pembiayaan Tidak Berbayar

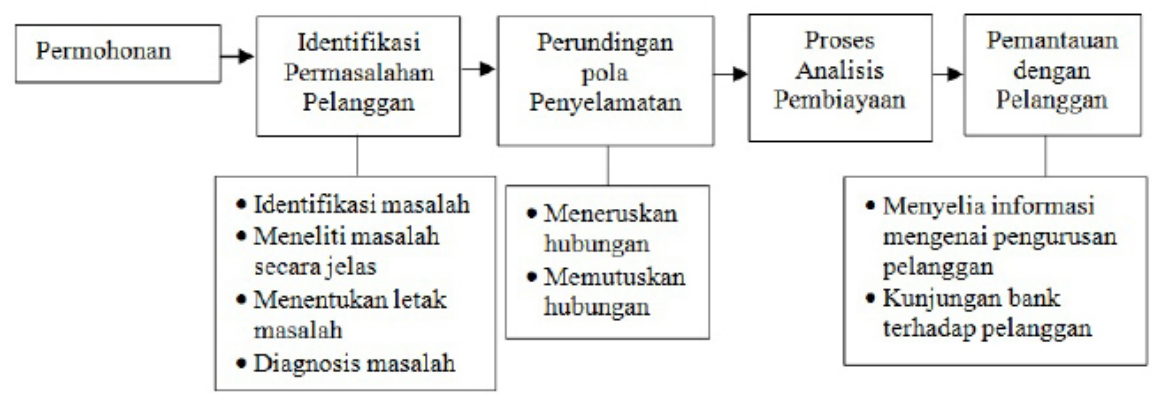

Sumber: Bank Syariah Mandiri Cawangan Dumai Indonesia ${ }^{35}$

\section{i) Mengenal pasti Permasalahan Pelanggan (Pengumpulan dan Pengesahan Data)}

Bagi mendapatkan data yang tepat dan relevan kunjungan perlu dilakukan ke lokasi perniagaan dan cagaran serta disokong informasi yang tepat. Sebelum melaksanakan penjadualan semula, Bank Syariah Mandiri Cawangan Dumai terlebih dahulu mencari maklumat mengenai permasalahan yang dihadapi oleh pelanggan dengan menemubual pelanggan yang berkaitan. Cara ini juga boleh dilakukan dengan berhubung melalui rakan perniagaan, surat khabar atau data Bank Indonesia. Perkara ini sangat diperlukan bagi Bank Syariah Mandiri Cawangan Dumai bagi mendapatkan maklumat yang tepat sebagai langkah awal penjadualan semula yang seterusnya. ${ }^{36}$ Analisis masalah penyelesaian merupakan bahagian pertama daripada cara menyelamatkan pembiayaan dengan menetapkan strategi, sebagaimana berikut: (1) mengenal pasti masalah melalui cara memfokuskan permasalahan, (2) mengkaji permasalahan secara

35 M. Restu al-Fahmi (Bahagian Pemasaran Bank Syariah Mandiri, Cawangan Dumai), dalam temu bual beliau bersama penulis pada 10 Januari 2015.

36 M. Restu al-Fahmi (Bahagian Pemasaran Bank Syariah Mandiri, Cawangan Dumai), dalam temu bual beliau bersama penulis pada 10 Januari 2015. 
jelas, misalnya penyebab pelanggan tidak mampu membayar ansuran, berapa lama pelanggan tidak membayar dan lain-lain,(3) mengenal pasti permasalahan lain di luar bank, contoh pelanggan mempunyai hutang dengan pihak lain, dan (4) menjalankan kajian bagi mengenal pasti permasalahan sehingga dapat ditentukan kadar kerugian yang akan terjadi.

\section{ii) Menawarkan Pola Penyelamatan}

Mengenal pasti permasalahan dapat memberikan kesimpulan awal yang mana akan dinyatakan kepada pelanggan tentang bentuk penyelamatan yang ditawarkan sesuai dengan kemampuan membayar. Bahagian pembiayaan perlu menetapkan suatu strategi bagi mengatasi permasalahan pelanggan. Penetapan strategi terbahagi kepada dua pilihan, iaitu; (1) Meneruskan perjanjian, strategi ini dipilih apabila pelanggan melihat ansuran dapat diselesaikan dengan baik tanpa sebarang tunggakan sama sekali, cara ini dipilih apabila pelanggan mempunyai harapan agar diselamatkan ansuran menjadi lebih baik, hingga tanpa tunggakan sama sekali. ${ }^{37}$ (2) Menamatkan perjanjian, dipilih kerana pelanggan tidak berkeinginan untuk meneruskan dengan cara meningkatkan prestasi. Menamatkan perjanjian dapat dilakukan dengan cara menjual cagaran. Pelanggan yang tidak memberikan kerjasama yang sepatutnya dapat dijadikan alasan oleh bank untuk menjual cagaran yang diberikan. Hal ini Kerana bank memerlukan komitmen pelanggan bagi melunaskan hutang pembiayaan. Pelanggan yang telah menggunakan pembiayaan untuk kepentingan peribadi pada masa yang sama mempunyai tunggakan kepada Bank Syariah Mandiri Cawangan Dumai turut ditamatkan perjanjian. ${ }^{38}$

\section{iii) Proses Analisis Pembiayaan}

Penilaian semula terhadap pembiayaan-pembiayaan bermasalah dilaksanakan dengan melihat keadaan dan prospek perniagaan pelanggan. Jika perniagaan mempunyai prospek yang baik untuk diteruskan, maka pembiayaan perlu dikira bagi melaksanakan penjadualan semula. Tujuan analisis pembiayaan adalah bagi mengenal pasti keputusan pembiayaan yang tepat. ${ }^{39}$

37 M. Restu al-Fahmi (Bahagian Pemasaran Bank Syariah Mandiri, Cawangan Dumai), dalam temu bual beliau bersama penulis pada 10 Januari 2015.

38 M. Restu al-Fahmi (Bahagian Pemasaran Bank Syariah Mandiri, Cawangan Dumai), dalam temu bual beliau bersama penulis pada 10 Januari 2015.

39 Arfan Maulana (Bahagian Pemasaran, Bank Syariah Mandiri, Cawangan Dumai, Indonesia), dalam temu bual beliau bersama penulis pada 20 Disember 2015. 


\section{iv) Pemantauan Terhadap Pelanggan}

Bank Syariah Mandiri Cawangan Dumai perlu kerap kali memperhatikan prestasi pelanggan dan perniagaannya, kerana ini sangat berkait dengan kualiti ansuran yang diberikan oleh pelanggan kepada bank. Pemantauan ini dapat dilaksanakan demi melihat komitmen pelanggan dalam usahanya untuk membayar ansuran seperti sumber dana dan maklumat yang diberikan pelanggan kepada bank mengenai apa sahaja yang dirasakan oleh pelanggan dalam perniagaannya selepas dilaksanakan penjadualan semula. ${ }^{40}$ Lawatan terhadap pelanggan, proses ini penting agar bank dapat lebih mengetahui keadaan pelanggan mahupun perniagaan. Dengan melakukan lawatan ke atas pelanggan, bank dapat mengesankan maklumat yang diberikan pelanggan kepada bank, misalnya melalui saudara pelanggan atau jiran. Jika pelanggan memiliki perniagaan, maka bank dapat memperoleh maklumat dari perniagaan seumpamanya yang berada di sekitar pelanggan. Usaha ini dilakukan bagi memperoleh data yang tepat sebagai bahan melaksanakan penjadualan semula pembiayaan. ${ }^{41}$

\section{v) Pemantauan dan Seliaan Penjadualan Semula}

Setelah penjadualan semula pembiayaan telah diproseskan, maka bank perlu melakukan seliaan yang ketat bagi memastikan pelanggan memenuhi seluruh syarat yang ditetapkan. Tindakan-tindakan yang dilakukan selepas penjadualan semula adalah; ${ }^{42}$ a) melakukan pengamatan semula pelaksanaan penjadualan semula, b) penilaian prospek perniagaan, c) penilaian aspek teknik pengeluaran, d) penilaian aspek pengurusan, e) penilaian aspek kewangan dan data analisis kewangan (terutama analisis arus khas) penghutang dengan laporan kewangan pelanggan, f) penilaian aspek lingkungan, dan g) menyusun langkah-langkah bagi mengatasi ketidakmampuan pelanggan dalam membayar setelah penjadualan semula.

40 M. Restu al-Fahmi (Bahagian Pemasaran Bank Syariah Mandiri, Cawangan Dumai), dalam temu bual beliau bersama penulis pada 10 Januari 2015.

41 M. Restu al-Fahmi (Bahagian Pemasaran Bank Syariah Mandiri, Cawangan Dumai), dalam temu bual beliau bersama penulis pada 10 Januari 2015.

42 M. Restu al-Fahmi (Bahagian Pemasaran Bank Syariah Mandiri, Cawangan Dumai), dalam temu bual beliau bersama penulis pada 10 Januari 2015. 


\section{ANALISIS TERHADAP PELAKSANAAN PEMBIAYAAN MIKRO DI BANK SYARIAH MANDIRI CAWANGAN DUMAI}

Prosedur pembiayaan mikro murābaḥah di Bank Syariah Mandiri Cawangan Dumai meliputi proses-proses yang dapat dibahagikan kepada tiga fasa iaitu $^{43}$ fasa permulaan pembiayaan, fasa masa pembiayaan dan fasa setelah pembiayaan. Ringkasnya fasa permulaan pembiayaan meliputi permohonan pembiayaan oleh pelanggan dengan disertakan syarat-syarat yang ditetapkan bank, selanjutnya dilakukan proses analisis pembiayaan permulaan oleh jawatankuasa pembiayaan. Jika mesyuarat jawatankuasa pembiayaan bersetuju, maka akan dilanjutkan dengan tinjauan kepada pelanggan yang dilakukan oleh penilai daripada pihak bank berkenaan. Data-data yang diperolehi daripada tinjauan ke pelanggan kemudian akan dibawa ke mesyuarat jawatankuasa pembiayaan yang mana ahlinya terdiri dari ketua pemasaran, penilai, bahagian kewangan dan kakitangan pemasaran.

Apabila suatu permohonan telah diluluskan oleh jawatankuasa pembiayaan, maka tahapan seterusnya adalah pemberian pembiayaan mengikut tahap-tahap seperti berikut; (1) mendapatkan persetujuan dengan pelanggan (termasuk di dalamnya perundingan tentang margin keuntungan, model pembayaran ansuran, pengikatan jaminan dan sebagainya). (2) Pemateraian akad murābaḥah berkenaan, (3) Pembacaan akad yang dihadiri oleh saksi daripada kedua-dua pihak. ${ }^{44}$ Berasaskan kepada penerangan tersebut, dapat dinyatakan bahawa prosedur pembiayaan pada fasa permulaan pembiayaan tidak didapati perkara yang bercanggah dengan ketentuan Syariah. Tinjauan kepada pelanggan yang dilakukan oleh penilai dari pihak bank merupakan langkah berjaga-jaga untuk menghindari kecuaian pelanggan, sekali gus salah satu bentuk dan wujud tanggungjawab terhadap amanah yang diberikan para penyimpan wang di bank. Ini sesuai dengan firman Allah SWT di dalam al-Quran:

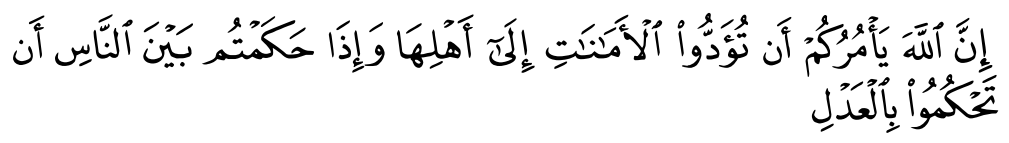

"Sesungguhnya Allah menyuruh kamu supaya menyerahkan segala jenis amanah kepada ahlinya (yang berhak menerimanya),

\footnotetext{
43 M. Restu al-Fahmi (Bahagian Pemasaran Bank Syariah Mandiri, Cawangan Dumai), dalam temu bual beliau bersama penulis pada 10 Januari 2015.

44 Arfan Maulana (Bahagian Pemasaran, Bank Syariah Mandiri, Cawangan Dumai, Indonesia), dalam temu bual beliau bersama penulis pada 20 Disember 2015.
} 


\section{dan apabila kamu menjalankan hukum di antara manusia, (Allah} menyuruh) kamu menghukum dengan adil."

(Surah al-Nisā', 4: 58)

Mesyuarat jawatankuasa pembiayaan dalam prosedur pembiayaan bererti forum mesyuarat untuk memutuskan sama ada permohonan pembiayaan diluluskan atau tidak. ${ }^{45}$ Keputusan yang diambil dalam mesyuarat yang melibatkan banyak pihak yang pakar dalam bidang masingmasing akan menghasilkan keputusan yang lebih muktamad dan dapat dipertanggungjawabkan. Mesyuarat jawatankuasa pembiayaan ini juga merupakan salah bentuk tanggungjawab pihak bank terhadap amanah yang diberikan para penyimpan wang di bank.

Tindakan bank untuk membuat kesepakatan dengan pelanggan (termasuk perundingan tentang margin keuntungan, model pembayaran ansuran, pengikatan jaminan dan sebagainya) menunjukkan bahawa akad mesyuarat antara pihak bank dengan pelanggan pembiayaan dilaksanakan berasaskan kesepakatan dan keredaan antara kedua-dua pihak. Hal ini selari dengan alQuran dan fuqaha'. ${ }^{46}$ Pembacaan akad perjanjian yang dihadiri saksi dari kedua-dua pihak yang menjadi bahagian prosedur pembiayaan murābahah di bank semakin mengukuhkan andaian bahawa akad murābahah yang dibuat antara bank dan pelanggan pembiayaan merupakan hasil kesepakatan dan keredhaan dari kedua-dua pihak. Tindakan ini menunjukkan sikap hati-hati pihak bank terhadap wang simpanan masyarakat yang merupakan amanah bagi bank untuk dilaburkan secara halal dan menguntungkan untuk menepati akad yang disepakati bersama. Kehadiran saksi membolehkan pelanggan didakwa di mahkamah jika terdapat sebarang kecuaian atau mungkir janji.

Setelah semua prosedur dan syarat-syarat dipenuhi, dalam hal pelaksanaan kontrak murābahah, pihak bank berperanan sebagai penjual barangan, pelanggan sebagai pembeli barangan. Kedua-dua pihak bersepakat melakukan

45 Al-Quran banyak menyebutkan perintah tentang musyawarah, misalnya Surah 'Āli 'Imrān [3]: 159; Surah al-Shūrā' 42: 38. Huraian lebih meluas tentang syura, musyawarah dan demokrasi boleh didapati dalam Dawam Raharjo, Ensiklopedia Al-Qur'ān, Tafsir Sosial Berdasarkan Konsep-Konsep Kunci (Jakarta: Paramadina, 2002), 440-460.

46 Lihat Muḥammad Ibn Aḥmad Ibn Muhammad Ibn Rushd, Bidāyah al-Mujtahid wa Nihāyah al-Muqtașid, vol. 216; 'Abd Allāh Ibn Aḥmad al-Maqdisī Ibn Qudāmah, al-Mughnī wa al-Sharh al-Kabìr, vol. 4, 102; Shams al-Dīn al-Shaykh Muhammad al-Dusūqī, Hāshiyah al-Dusūqī 'alā al-Sharh al-Kabīr, vol. 4 (Bayrūt: Dār al-Fikr, t.t.), 159; Al-Imām Kamāl al-Dīn Ibn Abd al-Rāḥid al-Sirāsi Ibn al-Ḥumām, Sharh Fath al-Qadīr, 252. 
kontrak jual beli barangan dengan harga jual dan tempoh masa yang disepakati bersama, dengan pembayaran secara ansuran. Pada hakikatnya, bank bukan penjual sepertimana industri perniagaan yang menjual secara langsung kepada pembeli kerana bank tidak mempunyai stok barangan. ${ }^{47}$ Model pelaksanaan akad murābahah sepertimana tersebut di atas, telah memenuhi syarat dan rukun kerana barangan yang dijadikan objek transaksi muräbahah telah benarbenar wujud, jelas dan bermanfaat, kerana menurut muamalat Islam, rukun akad muräbahah mewajibkan wujudnya barangan yang dijadikan objek akad. ${ }^{48}$

Pada semasa pembiayaan, bank melakukan kunjungan kepada pelanggan, memberikan seliaan dalam menguruskan keuntungan usaha dengan membahagikannya untuk membayar ansuran mahupun untuk tabungan supaya pengusaha dapat menikmati keuntungan pada masa hadapan dengan meningkatkan aset. ${ }^{49} \mathrm{Hal}$ ini akan mengeratkan hubungan antara pihak bank dan pelanggan, kerana model hubungan antara keduanya bukanlah setakat hubungan si pemiutang dan si penghutang dengan batas yang telah ditetapkan undang-undang, tetapi berasaskan nilai-nilai persaudaraan yang bersifat semulajadi. ${ }^{50}$ Dengan melakukan penyeliaan kepada pelanggan pembiayaan, pihak bank boleh mendapatkan keuntungan yang diperuntukkan kepadanya jika pelanggan membayar ansuran mengikut masanya. Lawatan ini juga membolehkan pihak bank mengetahui sebab kelewatan pelanggan membayar ansurannya, seperti keadaan terpaksa dan sebagainya. Merekod pembiayaan dengan baik sangat penting bagi institusi kerana data digunapakai untuk melakukan pengawasan dan penyeliaan..$^{51}$

Aktivit proses dokumentasi ini menjadikan urusan hutang-piutang dapat direkodkan dan dibuktikan secara tertulis. Semakin lengkap dokumentasi

47 M. Restu al-Fahmi (Bahagian Pemasaran Bank Syariah Mandiri, Cawangan Dumai), dalam temu bual beliau bersama penulis pada 10 Januari 2015.

48 Al-Sharbīn̄i Muhammad al-Khațīb, Mughnī al-Muhtāj, vol. 2, 253; Imām 'Alāw alDīn Abī Abū Bakr Ibn Mas'ūd al-Kāsān̄̄, Badā' ' i al-Sanā' $i$ ' fì Tartīb al-Sharā' $i$ ', vol. 7, 138; 'Abd al-Razzāq al-Sanhūrī, Mașādir al-Haq fì al-Fiqh al-Islāmī, vol. 3 (Bayrūt: al-Majma’ al-'Arabī al-Islāmī, 1981), 16.

49 M. Restu al-Fahmi (Bahagian Pemasaran Bank Syariah Mandiri, Cawangan Dumai), dalam temu bual beliau bersama penulis pada 10 Januari 2015.

50 Lihat pendedahan lebih luas lagi dalam Joni Tamkin Borhan, 'Falsafah Ekonomi dan Instrumen $M u$ 'āmalah dalam Amalan Perbankan Islam di Malaysia,' 115-140; Farhad Nomani \& Ali Rahnema, Islamic Economic Systems (London: Zed Books Ltd., 1994), 31-32; Joni Tamkin Borhan, 'The Tawhidic Paradigm in Islamic Banking,' Junal Usuluddin, 11 (2000): 45-58.

51 M. Restu al-Fahmi (Bahagian Pemasaran Bank Syariah Mandiri, Cawangan Dumai), dalam temu bual beliau bersama penulis pada 10 Januari 2015. 
pembiayaan maka semakin mudah untuk menunaikan amanah dan mempertanggungjawabkannya. Fasa seterusnya iaitu fasa setelah pembiayaan yang meliputi kegiatan menjalin ikatan lebih lama dengan cara mengunjungi kediaman pelanggan dan menawarkan pembiayaan baru. ${ }^{52}$ Fasa ini sangat penting kerana hubungan antara bank dan pelanggan bukanlah setakat hubungan pihak yang berhutang dengan had yang telah ditetapkan undangundang, tetapi berasaskan nilai-nilai persaudaraan yang bersifat semulajadi. Di samping itu, fasa ini penting bagi bank demi mengekalkan kelangsungan bank dalam mencari pelanggan yang sesuai dan setia. ${ }^{53}$

Margin keuntungan pembiayaan mikro murābaḥah ditentukan dengan cara perundingan antara pihak bank dan pelanggan. ${ }^{54}$ Cara penentuan margin keuntungan seperti ini telah memenuhi syarat-syarat akad murābahah, sepertimana yang dijelaskan oleh para ulama. ${ }^{55}$ Amalan ini menyerupai cara perniagaan yang dijalankan oleh Rasulullah SAW. Dalam menentukan harga jualan, Rasulullah SAW secara terperinci menjelaskan harga belinya, berapa kos yang telah dikeluarkan untuk setiap komoditi dan berapa keuntungan wajar yang diinginkan. ${ }^{56}$ Cara seperti yang dilakukan oleh Rasulullah SAW ini

52 M. Restu al-Fahmi (Bahagian Pemasaran Bank Syariah Mandiri, Cawangan Dumai), dalam temu bual beliau bersama penulis pada 10 Januari 2015.

53 Arfan Maulana (Bahagian Pemasaran, Bank Syariah Mandiri, Cawangan Dumai, Indonesia), dalam temu bual beliau bersama penulis pada 20 Disember 2015.

54 M. Restu al-Fahmi (Bahagian Pemasaran Bank Syariah Mandiri, Cawangan Dumai), dalam temu bual beliau bersama penulis pada 10 Januari 2015.

55 Misalnya dalam 'Abd al-Salām Ibn Sa'īd Habīb al-Tanūkhī Șaḥnūn, alMudawwanah al-Kubrā, vol. 3, 325; Muḥammad Ibn Aḥmad Ibn Muḥammad Ibn Rushd, Bidāyatul al-Mujtahid wa Nihāyahal-Muqtașid, jil. 2 (Bayrūt: Dār alQalam, 1988), 216; 'Abd Allāh Ibn Aḥmad al-Maqdisī Ibn Qudāmah, al-Mughnī wa al-Sharh al-Kabìr, vol. 4, 102.

56 Lihat Afzalur Rahman, Muhammad Blessing for Mankind (London: The Muslim School Trust London, 1979), 134-136; Afzalur Rahman, Muhammad: Encyclopedia of Seerah. Isnan et al. (terj.), Muhammad Sebagai Seorang Pedagang (Jakarta: Yayasan Swarna Bhumy, 1997), 24-28; Muhammad Husain Haekal, Hayat Muhammad. Ali Audah (terj.), Sejarah Hidup Nabi Muhammad (Kuala Lumpur: Dewan Bahasa dan Pustaka, 1981), 71-73; H.M.H. Al-Hamid AlHusain, Membangun Peradaban Sejarah Muhammad SAW Sejak Sebelum Diutus Menjadi Nabi (Bandung: Pustaka Hidayah, 2000), 224-226. 
merupakan salah satu cara yang sangat tepat dalam menentukan harga jualan terhadap barangan dengan akad murābahah. ${ }^{57}$

Amalan bank, dalam hal pengiraan jumlah margin keuntungan mempertimbangkan tempoh masa pembiayaan. Semakin lama tempoh masa, maka besarlah keuntungan yang diminta oleh bank. Jumhur ulama dari mazhab Hanafì, Shāfi‘n, mahupun Mālikîn ${ }^{58}$ dan para sarjana Islam kontemporari seperti Yusuf al-Qaraḍāwī, ${ }^{59}$ Rafīq Yūnus al-Mișrī, ${ }^{60}$ dan Muhammad 'Uthmān Shubayr ${ }^{61}$ mengharuskan untuk menaikkan harga disebabkan oleh penangguhan bayaran dengan syarat harga jualan telah dinyatakan dalam kontrak pada peringkat awal jual beli dilakukan. Secara lahiriah hal ini menyamai dengan pengiraan kadar faedah dalam pinjaman kredit di bank konvensional yang mempertimbangkan tempoh masa pembiayaan. Semakin lama tempoh masa kreditnya, maka semakin besarlah faedah yang dikenakan pihak konvensional terhadap peminjamnya.

Namun begitu, terdapat beberapa perbezaan antara pinjaman kredit yang berasaskan ribā di institusi kewangan konvensional dengan amalan akad murābaḥah Bank Syariah, antaranya sebagai berikut: (1) objek dalam akad murābahah berupa barangan wujud yang diperjualbelikan sehingga hutang pelanggan pembiayaan kepada bank adalah hutang kerana akad jual beli

57 Teori asas sistem kewangan pada bank konvensional adalah teori nilai wang. Teori tersebut dapat diilustrasikan seperti berikut: bahawa nilai wang RM1,000 pada masa sekarang akan berbeza dengan nilai wang RM1,000 pada masa lima tahun mendatang. Wang RM1,000 tersebut mempunyai kesempatan untuk menghasilkan wang. Terdapat dua perkara asas yang mendasari konsep tersebut: iaitu wujudnya inflasi dan preferensi kepenggunaan untuk masa sekarang daripada masa hadapan. Lihat Damadaron Aswath, Corporate Finance: Theory and Practice (New York: John Wiley \& Sons, 2001), 112. Lihat juga Muhammad Uzair, 'Some Conceptual and Practical Aspect of Interest Free Banking,' dalam Studies in Islamic Economis, ed. Khursid Ahmed (Leicester: The Islami Foundation; Jeddah: International Center for Research in Islamic Economics King Abdul Aziz University), 47.

58 Shams al-Dīn al-Shaykh Muḥammad al-Dusūqī, Hāshiyah al-Dusūqì 'alā alSharh al-Kabīr, vol. 3, 159; Muḥammad 'Alā al-Dīn Afnadī Ibn 'Ābidīn, Hāāsyiyah Ibn Ābidīn, vol. 4 (Bayrūt: Dār al-Ma‘rifah, 1996), 142; Al-Sharbīn̄̄ Muhammad al-Khațīb, Mughnī al-Muhtāj, vol. 2, 79.

59 Yūsuf al-Qaraḍawī, Bay ' al-Murābahah li al- 'Āmir bi al-Shirā' kama Tajrīh̄̄ alMașārif al-Islāmiyyah (Maktabah Wahbah, 1987), 26.

60 Rafĩq Yūnus al-Mișrī, al-Ribā wa al-Fā'idah, Dirāsah Iqtiṣādiyyah Muqāranah (Dimashq: Dār al-Fikr al-Mu'āṣir, 1999), 20.

61 Muhammad 'Uthmān Shubayr, al-Mu'āmalat al-Māliyyah al-Mu'āṣirah fì alFiqh al-Islāmī (Bayrūt: Dār al-Nafā' is, 1998), 266. 
barangan, sementara pinjaman kredit berasaskan ribā di institusi kewangan konvensional adalah perjanjian pinjam meminjam wang sehingga hutang itu wujud kerana pinjaman wang, (2) transaksi pembiayaan dengan akad murābahah berasaskan transaksi barangan yang diperjual belikan mesti jelas objek barangannya, sehingga transaksi itu merupakan transaksi sektor yang nyata, sementara pinjaman kredit berasaskan faedah di institusi kewangan konvensional tidak berdasarkan transaksi barangan yang diperjualbelikan, sehingga tidak jelas transaksi sektor utamanya, (3) Dalam transaksi murābaḥah, terdapat bukti pihak berkenaan bertanggungjawab mengadakan barangan tertentu dalam kes pihak bank mewakilkan kepada pelanggan untuk membeli barangan berkenaan di pasaran sebagaimana dalam perjanjian. ${ }^{62}$ Sementara pinjaman kredit berdasarkan faedah di institusi kewangan konvensional dalam kes pembiayaan kepenggunaan, pelanggan tidak bertanggungjawab membelikan barangan berkenaan.

\section{ANALISIS TINDAKAN PENTADBIR BANK SYARIAH MANDIRI CAWANGAN DUMAI TERHADAP KEGAGALAN PEMBAYARAN OLEH PELANGGAN}

Kelonggaran yang diberi bank iaitu tidak mengenakan sebarang caj lewat bayar antara sebab berlaku kegagalan pembayaran oleh pelanggan sama ada itu kerana mungkir bayar atau tangguh bayar. ${ }^{63}$ Keingkaran dan penangguhan ini disebabkan sikap enteng para pelanggan untuk menjelaskan bayaran tepat pada masanya di samping terdapat juga beberapa pelanggan yang benar-benar menghadapi masalah kesempitan wang sehingga gagal membuat bayaran ansuran sebagaimana yang dijanjikan. ${ }^{64}$ Murābaḥah sebagai instrumen

62 M. Restu al-Fahmi (Bahagian Pemasaran Bank Syariah Mandiri, Cawangan Dumai), dalam temu bual beliau bersama penulis pada 10 Januari 2015.

63 Muhammad Taqi Usmani, An Introduction to Islamic Finance, 55; Saad al-Harran (t.t.), Islamic Banking: Managing The Challenges (Kuala Lumpur: Institut Kajian Dasar), 22; Ahmad Maulidizen, 'Islamic Finance in Theory and Practice: A Critical Analysis,' Jurnal IslamiConomics, 8/2 (2018): 111-140.

64 Nor Azizah Kamri \& Fadillah Mansor, 'Aplikasi Konsep al-Murābaḥah dalam penawaran Instrument di Institusi Perbankan Islam di Malaysia,' Prosiding Seminar Kewangan Islam, Akademi Pengajian Islam Universiti Malaya, Kuala Lumpur (18 Jun 2002), 138. 
pembiayaan yang paling popular ${ }^{65}$ diamalkan oleh perbankan Syariah di Indonesia mencatatkan rekod kegagalan pembayaran paling tinggi. Bank Syariah Mandiri Cawangan Dumai melaporkan bahawa peratusan pembiayaan tidak berbayar sebanyak $4.29 \% .{ }^{66}$ Oleh yang demikian pihak pengerusi dalam menghadapi kes kegagalan pembayaran telah menggunakan pendekatan pujukan dan kekeluargaan. ${ }^{67}$ Wujudnya toleransi masa kelewatan selama 3 hari pada setiap ansuran sepertimana tersebut dalam kontrak akad pembiayaan murābaḥah di Bank Syariah Mandiri Cawangan Dumai ${ }^{68}$ menunjukkan sikap kemanusiaan pihak pentadbir Bank Syariah Mandiri Cawangan Dumai terhadap pelanggan.

Akan tetapi jika terjadinya keingkaran dan penangguhan bayaran ansuran ini disebabkan kerana sikap ambil mudah para pelanggan untuk menjelaskan bayaran tepat pada masanya, tentu ini merupakan suatu bentuk kezaliman yang dilakukan oleh pihak pelanggan terhadap bank. Sikap ini harus dihukum supaya tidak mengulangi tindakannya. Rasulullah SAW bersabda sepertimana berikut:

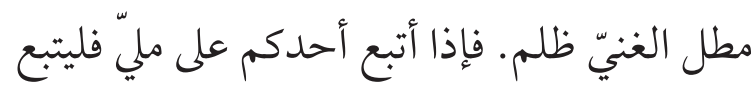

"Penangguhan (melalaikan) pembayaran hutang (padahal ia mampu) merupakan suatu bentuk kezaliman yang dapat dikenakan hukuman dan dicemarkan nama baiknya (disenaraihitamkan). " 69

Tindakan pihak pentadbir dalam menyelesaikan kes kegagalan pembayaran dengan sistem kekeluargaan (di mana pihak bank akan mencari solusi dengan mencari informasi dan kemungkinan-kemungkinan untuk menyelesaikan

65 Secara realitinya perbankan Syariah lebih banyak mengamalkan instrumen murābahah yang kadarnya mencapai $82 \%$ dari keseluruhan pembiayaan yang dilakukan. Mohamed Alli Elgari, 'Credit Risk in Islamic Banking and Finance,' 21-22. Lihat pula Muhammad Nejatullah Siddiqi, 'Islamic Bank: Concept, Precept and Prospect,' 29; Fuad Abdullah Omar \& Munawar Iqbal, 'Some Strategic Suggestion for Islamic Banking in the 21st Century: Review of Islamic Economics,' 42-43.

66 Laporan Kewangan Tahun 2014 Bank Syariah Mandiri.

67 M. Restu al-Fahmi (Bahagian Pemasaran Bank Syariah Mandiri, Cawangan Dumai), dalam temu bual beliau bersama penulis pada 10 Januari 2015.

68 Contoh sampel surat kontrak akad pembiayaan murābahah di Bank Syariah Mandiri; M. Restu al-Fahmi (Bahagian Pemasaran Bank Syariah Mandiri, Cawangan Dumai), dalam temu bual beliau bersama penulis pada 10 Januari 2015.

69 Al-Bukhārī, Șah̄ịh al-Bukhārī (Riyāụ: Bayt al-Afkār al-Dawliyyah, 2012), hadis no. 2400 dengan pendedahan Aḥmad Ibn 'Alī Ibn Hajar al-'Asqalānī, Fath al$B \bar{a} r \bar{r}$, vol. 5 (Rawḍah: Maṭba'ah al-Salafiyyah wa Maktabatuha, 1401H), 62. 
kewajiban pelanggan daripada sumber pendapatan pelanggan itu sendiri), ${ }^{70}$ menunjukkan bahawa hubungan antara keduanya bukanlah setakat hubungan pihak pemberi hutang dan penerima hutang dengan batas yang telah ditetapkan undang-undang, tetapi berasaskan nilai-nilai Syariah. ${ }^{71}$ Selanjutnya pihak bank akan; a) menghubungkan silaturahim dengan mengingatkan tentang kewajipan ansuran pelanggan, (b) Jika dalam tempoh masa tiga hari, pelanggan belum juga membayar ansuran, maka bank menguatkan silaturahim sekali lagi untuk mengingatkan tentang kewajipan ansuran pelanggan, (c) Jika telah lewat masa tiga hari setelah peringatan tersebut, pihak bank mengirimkan surat teguran sehingga tiga kali (SP 1, 2 dan 3), (d) Jika setelah itu pelanggan masih belum mampu membayar ansuran, maka kontrak diubah menjadi pembiayaan qard al-hasan, berdasarkan kontrak baru, ini pelanggan hanya mengembalikan wang pinjaman asal sahaja. Pendekatan terakhir adalah dengan menarik barang yang telah dibeli dengan wang yang diberikan institusi, kemudian dimanfaatkan atau dijual secara bersama-sama dan hasilnya untuk menyelesaikan kewajipan pelanggan. Sekiranya terdapat baki wang, maka diberikan kepada pelanggan berkenaan. ${ }^{72}$

\section{ANALISIS PELAKSANAAN PENJADUALAN SEMULA PEMBIAYAAN MIKRO MURĀBAHAH BANK SYARIAH MANDIRI CAWANGAN DUMAI MENURUT HUKUM ISLAM DAN FATWA DEWAN SYARIAH}

Merujuk kepada Fatwa Dewan Syariah Nasional Majlis Ulama Indonesia No. 48/DSN-MUI/II/2005 tentang Penjadualan Semula Agihan Murābaḥah. Terdapat syarat-syarat terhadap pelanggan yang ingin melakukan penjadualan semula iaitu a) potensi perniagaan memiliki prospek yang baik, b) pelanggan memiliki kemampuan untuk menjalankan perniagaannya tetapi mengalami sedikit permasalahan, c) adanya masalah dalam aliran wang perniagaan dan d) pembiayaan yang diberikan tetap seperti semula.

70 M. Restu al-Fahmi (Bahagian Pemasaran Bank Syariah Mandiri, Cawangan Dumai), dalam temu bual beliau bersama penulis pada 10 Januari 2015.

71 Lihat pendedahan lebih luas lagi dalam Joni Tamkin Borhan, 'Falsafah Ekonomi dan Instrumen $M u$ 'àmalah dalam Amalan Perbankan Islam di Malaysia,' 115-140; Farhad Nomani \& Ali Rahnema, Islamic Economic Systems, 31-32; Joni Tamkin Borhan, 'The Tawhidic Paradigm in Islamic Banking,' 45-58.

72 M. Restu al-Fahmi (Bahagian Pemasaran Bank Syariah Mandiri, Cawangan Dumai), dalam temu bual beliau bersama penulis pada 10 Januari 2015. 
Penjadualan semula pembiayaan murābaḥah dilaksanakan oleh bank Syariah merupakan bentuk perkhidmatan terhadap pelanggan yang mengalami kesulitan membayar kewajipannya. Penjadualan semula bertujuan memberikan keringanan kepada pelanggan dalam ansuran pembiayaan mikro murābaḩah. Pelanggan berpeluang memperoleh potongan berupa pengurangan pembayaran ansuran. Potongan diberikan kepada pelanggan bersandarkan kepada ketetapan dalaman Bank Syariah Mandiri Cawangan Dumai, tapi bank tidak memberikan kepastian tentang potongan hutang pembiayaan mikro murābahah hanya menyatakan bahawa dalam praktik mereka dapat memberikan potongan atau tidak berdasarkan ketetapan dalaman bank pada saat analisis kemampuan pelanggan dalam membayar ansuran. ${ }^{73}$

Bank Syariah Mandiri Cawangan Dumai berpandukan pada persyaratan Pasal 126 Kompilasi Hukum Ekonomi Syariah tentang syarat penjadualan semula, iaitu penjual dapat melakukan penjadualan semula hutang murābahah kepada pelanggan yang tidak dapat melunasi hutang sesuai dengan jumlah dan tempoh masa yang telah dipersetujui dengan ketentuan 1) Tidak menambah jumlah baki hutang, 2) Pembebanan kos dalam proses penjadualan semula adalah kos sebenar, 3) Perpanjangan masa pembayaran harus berdasarkan kesepakatan para pihak. Ketetapan tidak menambah jumlah baki hutang menjadi intipati dalam menentukan penjadualan semula. Jumlah ansuran pelanggan sebelum dan sesudah penjadualan semula adalah sama. Jumlah ansuran yang lebih banyak atau berlebih sama dengan riba. Ketentuan lainnya pembebanan kos dalam proses penjadualan semula adalah kos sebenar. Kos sebenar yang dimaksudkan adalah kos administrasi.

Dalam pelaksanaan penjadualan semula pembiayaan mikro murābaḥah bermasalah, didapati Bank Syariah Mandiri Cawangan Dumai tidak mengamalkan syarat yang ada dalam fatwa secara menyeluruh kerana bank membebankan pelanggan dengan pelbagai kos penjadualan semula antaranya kos penjadualan semula hingga ansuran pelanggan semakin tinggi. Menurut keterangan Fahmi, kos tersebut dibebankan kepada pelanggan. ${ }^{74}$ Denda tidak dimasukkan ke dalam kos sebenar, kerana dalam penjadualan semula sebenarnya tidak ada denda. Penambahan kos sebenar dalam penjadualan semula dibenarkan hukum Islam. Penambahan kos yang dilarang adalah kos yang mengarah pada keuntungan bank seperti denda kerana keterlambatan dan kos penambahan pembayaran akibat dari penangguhan hutang murābahah.

73 M. Restu al-Fahmi (Bahagian Pemasaran Bank Syariah Mandiri, Cawangan Dumai), dalam temu bual beliau bersama penulis pada 10 Januari 2015.

74 M. Restu al-Fahmi (Bahagian Pemasaran Bank Syariah Mandiri, Cawangan Dumai), dalam temu bual beliau bersama penulis pada 10 Januari 2015. 
Penambahan denda keterlambatan tersebut tidak dibenarkan dalam hukum Islam kerana termasuk riba. Di sini riba berlaku antara bank dan pelanggan. Ketidakmampuan pelanggan membayar tidak dapat dikenakan denda kerana pelanggan dalam kesulitan. Keuntungan yang diperoleh dari denda pelanggan sebagai bentuk kezaliman terhadap kesulitan orang lain. ${ }^{75}$

Sebelum melakukan penjadualan semula, terlebih dahulu pihak bank akan membuat lawatan ke lokasi perniagaan pelanggan. Bagi mendapatkan maklumat tentang punca berlakunya penurunan bayaran ansuran dan pelanggan mempunyai perniagaan yang mempunyai prospek baik dan dapat diselamatkan, sehingga Bank Syariah Mandiri Cawangan Dumai mengharapkan setelah berlaku penjadualan semula, pelanggan dapat melakukan semula ansuran. Hal ini dilakukan untuk menyelamatkan pelanggan dari pembiayaan bermasalah berkait ansuran yang harus dipenuhi sebagaimana sebelum pembiayaan dipersetujui. Mesyuarat antara pihak bank dan pelanggan merupakan langkah awal untuk membantu pelanggan keluar dari masalah.

Menurut Fatwa Dewan Syariah Nasional, bank Syariah hanya dibolehkan mengenakan pelanggan kos sebenar yang diperlukan melaksanakan penjadualan semula. Dalam masalah kos penjadualan semula pembiayaan murābahah, Dewan Pengawas Syariah Bank Syariah Mandiri Cawangan Dumai terbahagi dalam dua kelompok, iaitu "pihak yang membolehkan" dan "pihak yang mengharamkan". Sebahagian kelompok Dewan Pengawas Syariah Bank Syariah yang membolehkan kos tersebut dan mengakuinya

75 Dalam Surah al-Baqarah 2: 280, menyatakan bahawa, "dan jika orang yang berhutang itu sedang mengalami kesempitan hidup, maka berilah tempoh sehingga ia lapang hidupnya dan (sebaliknya) bahawa kamu sedekahkan hutang itu (kepadanya) adalah lebih baik untuk kamu, kalau kamu mengetahui (pahalanya yang besar yang kamu akan dapati kelak)". Hadis Nabi riwayat alBayhaqī dan Ibn Mājah dan disahihkan oleh Ibn Hibban, menyatakan "Dari Abū Sa‘̄̄d al-Khudrī bahawa Rasulullah SAW bersabda: Sesungguhnya jual beli itu hanya boleh dilakukan dengan kedua belah pihak". Hadis Nabi riwayat Muslim menyatakan bahawa Nabi SAW bersabda: "Orang yang melepaskan seorang Muslim dari kesulitannya di dunia, Allah akan melepaskan kesulitannya di hari kiamat; dan Allah sentiasa menolong hamba-Nya selama ia (suka) menolong saudaranya. Hadis riwayat Tirmidhi dari 'Amr bin 'Awf al-Muzani menyatakan Nabi SAW bersabda, "Perjanjian dapat dilakukan di antara kaum Muslimin kecuali perdamaian yang mengharamkan yang halal atau menghalalkan yang haram; dan kaum Muslimin terikat dengan syarat-syarat mereka, kecuali syarat yang mengharamkan yang halal atau menghalalkan yang haram. " Lihat Taufiqul Hulam \& Muhammad Muzani, 'Penjadualan Semula Hutang Murabahah di Bank Rakyat Indonesia Syariah Cawangan Pekanbaru Berdasarkan Hukum Islam,' Jurnal Perspektif Hukum, 16/1 (2016): 60-74. 
sebagai pendapatan bagi pihak bank, pembebanan kos tersebut dengan alasan, antaranya 1) bank mesti memberikan pulangan atau keuntungan kepada pendeposit akaun tabungan, 2) memberikan hukuman kepada pelanggan dan masyarakat awam agar tidak melakukan hal serupa, dan 3) bank menggunakan wang pendeposit dalam beroperasi. Selain itu yang menjadi isu lain adalah denda yang dikenakan dianggap keuntungan oleh bank. ${ }^{76}$

Dalam melihat isu tersebut, pengkaji lebih bersetuju membolehkan pengenaan kos sebenar penjadualan semula kepada pelanggan pembiayaan mikro murābahah seperti kos pentadbiran dan mengenakan denda atau penalti. Bank boleh mengenakan denda kepada pelanggan yang gagal membayar dengan syarat tidak melebihi hutang. Pihak bank tidak diharuskan mendapat bahagian sedikitpun daripada wang denda tersebut. Hal ini juga boleh memberikan peringatan kepada pelanggan lainnya agar tidak ambil mudah terhadap wang yang telah dipinjam dari bank. Jika pelanggan belum mampu membayar hutangnya ketika tempoh matang, maka bank bersedia memanjangkan tempoh pembayaran ansuran. ${ }^{77}$ Manakala denda yang dikenakan kepada pelanggan tidak boleh dianggap keuntungan oleh bank kerana bukan merupakan ganti rugi pembiayaan. Pendapat pengkaji ini pula disokong oleh pendapat para seperti Kamāl Hammad, Ali Elgari, Nejatullah Siddiqi dan Akademi Fikah Islam.

76 Dewan Pengawas Syariah yang mengharamkan adanya kos penjadualan semula Sل قرض جرّ منفعة" " ئ "ertinya "setiap hutang yang mendatangkan manfaat atau lebih adalah riba. Kos penjadualan semula hanya kos sebenar sahaja yang dikenakan kepada pelanggan dan dianggap sebagai dana kebajikan atau ganti rugi kerana kegagalan pelanggan dan bank tidak dibolehkan mengambil sebagai pendapatan. Manakala Dewan Pengawas Syariah yang membolehkan bersandarkan kepada kaedah fiqh muamalat al-ḍrūrah tubīh al-maḩ̣ūrāt yang bermaksud terdapat keadaan darurat atau bahaya yang amat berat kepada diri manusia, yang membuatkan dia khuatir akan terjadinya kerosakan atau sesuatu yang menyakiti jiwa, anggota tubuh badan, kehormatan, akal, harta dan yang bersangkutan dengannya. Adanya kos penjadualan semula yang dikenakan kepada pelanggan dibolehkan dengan tujuan menjaga harta pelanggan pendeposit.

77 Sarjana Islam dan ahli tafsir melihat masalah riba ini dari segi hukumnya sahaja iaitu haram, namun masih belum ada yang membincangkannya dari sisi ilmu ekonomi. Lihat Mardani, Ayat-ayat dan Hadīth Ekonomi Syariah (Jakarta: Rajawali Press Persada, 2011), 17; Ahmad Maulidizen, 'A Critical Analysis of Islam, Economy and Finance in the Early $21^{\text {st }}$ Century,' Jurnal Hukum Islam, vol. 16/2 (2018): 132-151. 
Dalam mengatasi pembiayaan mikro murābahah, pihak Bank Syariah Mandiri Cawangan Dumai melakukan penjadualan semula bagi pelanggan yang mengalami penurunan ansuran. Maka berdasarkan surah tersebut, pengkaji memberikan cadangan bagi Bank Syariah Mandiri Cawangan Dumai dalam melaksanakan penjadualan semula pembiayaan mikro murābahah dalam tiga peringkat sepertimana berikut:

\section{i) Memberikan tempoh masa sehingga pelanggan berkelapangan}

Memberikan tempoh masa sehingga pelanggan berkelapangan, dengan penangguhan atau penjadualan pembayaran semula tersebut, diharapkan pelanggan mempunyai kemampuan membayar kembali kewajipanya sehingga lunas hutang tersebut. Kemampuan untuk membayar kembali disebabkan kerana perniagaan pelanggan dapat berjalan sebagaimana mestinya setelah penjadualan semula. Sebagaimana dijelaskan di dalam al-Quran:

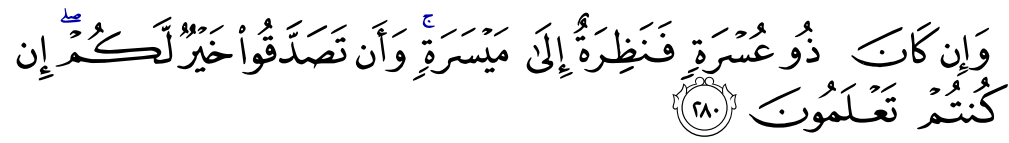

"Dan jika orang yang berhutang itu sedang mengalami kesempitan hidup, maka berilah tempoh sehingga ia lapang hidupnya dan (sebaliknya) bahawa kamu sedekahkan hutang itu (kepadanya) adalah lebih baik untuk kamu, kalau kamu mengetahui (pahalanya yang besar yang kamu akan dapati kelak)."

(Surah al-Baqarah, 2: 280)

Pemberian tempoh masa yang dimaksudkan adalah penambahan tempoh masa pembiayaan tanpa adanya kos yang dibebani kepada pelanggan. Ini kerana dalam keadaan seperti ini, pelanggan sedang dalam kesukaran untuk membayar tetapi bank memberikan kos dalam penjadualan semula dan hal ini hanya menambah beban pelanggan dan tidak selaras dengan ketentuan sebagaimana dinyatakan dalam hadis di atas.

\section{ii) Penjadualan semula dengan mengenakan kos sebenar sahaja}

Bank dapat melakukan penjadualan semula kepada pelanggan tanpa mengenakan kos apapun kecuali yang dibenarkan dalam fatwa Dewan Syariah Syariah. Kos yang diterima bukan sebagai pendapatan atau keuntungan, tetapi 
sebagai ganti rugi terhadap kos yang telah dikeluarkan dalam penjadualan semula. Hal ini sesuai dengan hadis Nabi SAW sepertimana berikut:

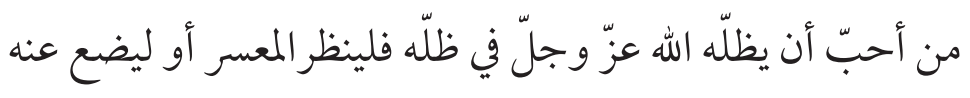

"Barangsiapa ingin diselamatkan Allah SWT dari kesukaran hari kiamat, maka hendaklah ia memberi tangguhan kepada orang yang kesukaran atau membebaskan hutangnya.." 78

Dalam hadis lain dijelaskan bahawa apabila seorang berhutang dan mengalami kesukaran dalam membayarnya, maka kepada peminjam bersangkutan diberikan kelapangan untuk membayar hutangnya oleh pihak yang memberi pinjaman. Mengenai penyelesaian hutang-piutang, Rasulullah SAW telah memberikan beberapa pedoman sebagaimana dalam sebuah hadis berikut:

$$
\begin{gathered}
\text { مطل الغنيّ ظلم "menunda-nunda pembayaran hutang yang dilakukan oleh orang } \\
\text { yang mampu adalah sebuah suatu kezaliman.” } 79
\end{gathered}
$$

\section{iii) Penukaran akad pembiayaan murābaḥah kepada pembiayaan qarḍ}

Dalam kes kegagalan pembayaran pembiayaan mikro murābahah yang berlaku setelah penjadualan semula dilakukan, maka tindakan yang dapat dilakukan oleh bank ialah menukarkan akad pembiayaan murābahah kepada pembiayaan qard. Ertinya bank tidak mendapatkan bayaran keuntungan dari pelanggan tetapi hanya pembayaan pokok hutang sahaja. Hal ini lebih baik untuk menyelamatkan wang pendeposit yang telah diberikan oleh pendeposit.

\section{KESIMPULAN}

Dalam pelaksanaan penjadualan pembiayaan mikro murābahah, Bank Syariah Mandiri Cawangan Dumai mesti mengikuti Fatwa Dewan Syariah Nasional Indonesia khasnya No 48 tentang penjadulan semula. Terdapat tiga ketetapan iaitu; 1) tidak menambah jumlah tuntutan dari baki hutang yang ada, 2) pengenaan kos dalam proses penjadualan semula adalah kos sebenar, dan 3) memanjangkan masa pembayaran perlu berdasarkan perjanjian kedua-dua pihak. Dari ketiga ketetapan tersebut, bank hanya melakukan dua iaitu tidak

\footnotetext{
78 Abī 'Abd Allāh Muḥammad Ibn Ismā‘īl al-Bukhārī, Șaḥịh al-Bukhārī, 265.

79 Muhammad Ibn 'Īsā al-Tirmidhī, Sunān al-Tirmidhī (al-Jāmī' al-Șaḥīh), vol. 2 (Qāhirah: Maktabah al-Bābī al-Ma'rifah al-Ḥalabī, 1967), 9.
} 
menambah jumlah baki tuntutan dan memanjangkan masa pembayaran perlu berdasarkan perjanjian kedua-dua pihak. Sedangkan bank masih membebani pelanggan dengan adanya kos penjadualan semula yang dapat menyusahkan pelanggan. Oleh yang demikian, terdapat tiga cadangan daripada pengkaji, iaitu memberikan kelapangan masa pembayaran, melakukan penjadualan semula tanpa adanya kos yang dibebankan kecuali kos sebenar dan penukaran akad pembiayaan murābaḥah menjadi akad pembiayaan qarḍ.

\section{RUJUKAN}

'Abd Allāh Ibn Aḥmad al-Maqdisī Ibn Qudāmah, al-Mughnī wa al-Sharh alKabīr, vol. 4 (Bayrūt: Dār al-Kutub al-'Arabī, 1972).

'Abd al-Razzāq al-Sanhūrī, Maṣādir al-Haq fì al-Fiqh al-Islāmī, vol. 3 (Bayrūt: al-Majma’ al-'Arabī al-Islāmī, 1981).

'Abd al-Salām Ibn Sa'īd Habīb al-Tanūkhī Șahnūn, al-Mudawwanah alKubrāa, vol. 3 (Bayrūt: Dār al-Ṣadīr, t.t.).

Abdullah Saeed, Islamic Banking and Interest: A Study of the Prohibition of Ribā and Its Contemporary (Leiden: E.J. Brill, 1996).

Abī 'Abd Allāh Muḥammad Ibn Ismā'̄il al-Bukhārī, Șaḥ̄ḥ al-Bukhārī, Kitāb al-Istiqrāẹ (Riyāḍ: Bayt al-Afkār al-Dawliyyah, 2012).

Abū al-Faḍll Jamāl al-Dīn Muhammad Ibn Mukarram Ibn Manẓūr, Lisān al'Arab, vol. 4 (Qāhirah: al-Dār al-Mișriyyah li al-Ta'līf wa al-Tarjamah, 1954).

Abū Zakariyyā Muḥy al-Dīn bin Sharf al-Nawawī, Rawḍh al-Ṭālibīn (alMaktab al-Islāmī li al-Tabā' wa al-Nashr, t.t.).

Adiwarman Karim, Bank Islam (Analisis Fiqih dan Kewangan) (Jakarta: PT. Raja Grafindo Persada, 2004).

Adiwarman Karim, Sejarah Pemikiran Ekonomi Islam (Jakarta: PT. Raja Grafindo Persada, 2004).

Adrian Sutedi, Perbankan Syariah Tinjauan dan Beberapa Segi Hukum (Bogor: Ghalia Indonesia, 2009).

Afzalur Rahman, Muhammad Blessing for Mankind (London: The Muslim School Trust London, 1979).

Aḥmad Ibn 'Alī Ibn Hajar al-'Asqalānī, Fatḥ al-Bārī, vol. 5 (Rawḍah: Mațba'ah al-Salafiyyah wa Maktabatuha, 1401H).

Ahmad Maulidizen \& Joni Tamkin Borhan, 'Aplikasi Pembiayaan Modal Kerja Murābahah bi al-Wakālah: Studi Kasus Pada Bank Muamalat Indonesia Cabang Sungkono Surabaya,' Jurnal Ilmiah Islam Futura, 16/1 (2016): 91-109. 
Ahmad Maulidizen \& Mohammad Taqiuddin Mohamad, 'Murābahah Sebagai Instrumen Pembiayaan dalam Keuangan Islam Modern,' Jurnal Ijtimiyyah, 11/1 (2018): 303-332.

Ahmad Maulidizen, 'A Critical Analysis of Islam, Economy and Finance in the Early $21^{\text {st }}$ Century,' Jurnal Hukum Islam, vol. 16/2 (2018): 132-151.

Ahmad Maulidizen, 'Islamic Finance in Theory and Practice: A Critical Analysis,' Jurnal IslamiConomics, 8/2 (2018): 111-140.

Ahmad Maulidizen, 'Penjadualan Semula Pembiayaan Mikro Murābaḥah di Bank Syariah Mandiri, Indonesia,' Disertasi Sarjana, Jabatan Syariah dan Ekonomi, Akademi Pengajian Islam, Universiti Malaya, Kuala Lumpur, 2016).

Al-Fīrūzābādī, al-Qāmūs al-Muḥ̂ț, vol. 1 (Bayrūt: Dār al-Fikr, 1983).

Al-Imām Kamāl al-Dīn 'Abd al-Rāḥid al-Sirāsi Ibn al-Humām, Sharḥ Fatḥ al-Qadīr, vol. 5 (Bayrūt: Dār al-Kutub al-'Ilmiyyah, 1970).

Al-Ṣādiq Muhammad al-Amīn al-Ḍarīr, 'al-Ittifāq 'alā Ilzām al-Madīn alMu'sir bi Ta'wīd Darar al-Mumāthilah,' Journal of Research in Islamic Economic, 3/1 (1985): 111-112.

Al-Sharbīn̄i Muḥammad al-Khațīb, Mughnī al-Muhtājj, vol. 2 (Qāhirah: Sharīkah Maktabah wa Maṭba'ah al-Mușțafā al-Bābī al-Ḥalābī wa Awlādih, 1958).

AS. Mahmoeddin, 100 Penyebab Kredit Macet (Jakarta: Pustaka Sinar Harapan, 1994).

Ascarya, Akad dan Produk Bank Syariah (Jakarta: Rajawali Press, 2011).

Burhanuddin S., Aspek Hukum Lembaga Kewangan Syariah (Yogyakarta: Graha Ilmu, 2010).

Damadaron Aswath, Corporate Finance: Theory and Practice (New York: John Wiley \& Sons, 2001).

Dawam Raharjo, Ensiklopedia Al-Qur'ān, Tafsir Sosial Berdasarkan KonsepKonsep Kunci (Jakarta: Paramadina, 2002).

Dewi Nurul Musjtari, Penyelesaian Sengketa Operasional Bank Syariah (Yogyakarta: Nuha Medika, 2000).

Faisal, 'Rektrukturiasi Pembiayaan Murabahah dalam Mendukung Manajemen Resiko Sebagai Implementasi Prudential Principle Pada Bank Syariah di Indonesia,' Jurnal Dinamika Hukum, 11/3 (2011), 463-471.

Farhad Nomani \& Ali Rahnema, Islamic Economic Systems (London: Zed Books Ltd., 1994). 
Fuad Abdullah Omar \& Munawar Iqbal, 'Some Strategic Suggestion for Islamic Banking in the 21st Century: Review of Islamic Economics,' Journal of the International Association for Islamic Economics and the Islamic Foundation, 9 (2000), 42-43.

H.M.H. Al-Hamid Al-Husain, Membangun Peradaban Sejarah Muhammad SAW Sejak Sebelum Diutus Menjadi Nabi (Bandung: Pustaka Hidayah, 2000).

Harun Nasution, Akal dan Wahyu dalam Islam (Jakarta: UI Press, 1986).

Imām 'Alāw al-Dīn Abī Abū Bakr Ibn Mas'ūd al-Kāsānī, Badā ’i ' al-Ṣanā'i ‘ fì Tartīb al-Sharā'i', vol. 5 (Bayrūt: Maṭba'ah al-'Āṣimah, t.t.).

J. Michael Taylor, 'Islamic Banking the Feasibility of Establishing an Islamic Bank in the United State,' American Business Law Journal, 40 (2003).

Joni Tamkin Borhan, 'Bay 'al-Murābaḥah in Islamic Commercial Law,' Jurnal Syariah, 6 (1998): 53-58.

Joni Tamkin Borhan, 'Falsafah Ekonomi dan Instrumen $M u$ 'āmalah dalam Amalan Perbankan Islam di Malaysia,' Jurnal Usuluddin, 13 (2001): 115-140.

Joni Tamkin Borhan, 'The Tawhidic Paradigm in Islamic Banking,' Junal Usuluddin, 11 (2000): 45-58.

Mardani, Ayat-ayat dan Hadith Ekonomi Syariah (Jakarta: Rajawali Press Persada, 2011).

Mohamed Alli Elgari, 'Credit Risk in Islamic Banking and Finance,' Islamic Economic Studies, 10/2 (2003): 21-22.

Mohammad Ali Elgari, Mohammad Nejatullah Siddiqi \& Mohammad Anas Zarqa, 'Qanun al-Masarif-Sighah Muqtarahah li Tanzim Qita' fi alMasaraf al-Islami,' Review of Islamic Economics, 2/2 (1993): 67-97.

Muhammad 'Alā al-Dīn Afnadī Ibn 'Ābidīn, Hāsyiyah Ibn Ābidīn, vol. 4 (Bayrūt: Dār al-Ma'rifah, 1996).

Muḥammad 'Uthmān Shubayr, al-Mu 'àmalat al-Māliyyah al-Mu 'āṣirah fí alFiqh al-Islāmī (Bayrūt: Dār al-Nafā' is, 1998).

Muḥammad bin Idrīs al-Shāfi‘̄̄, al-Umm (Qāhirah: Dār al-Sha ‘b, 1968).

Muhammad Fadel, 'Shari'a: Islamic Law in Contemporary Contex,' Journal of Law and Religion, 24 (2009): 102.

Muhammad Ibn 'Īsā al-Tirmidhī, Sunān al-Tirmidhī (al-Jāmī' al-Saḥ̄hh), vol. 2 (Qāhirah: Maktabah al-Bābī al-Ma'rifah al-Halabī, 1967).

Muḥammad Ibn Aḥmad Ibn Muḥammad Ibn Rushd, Bidāyah al-Mujtahid wa Nihāyah al-Muqtașid, vol. 2 (Bayrūt: Dār al-Qalam, 1988). 
Muhammad Nejatullah Siddiqi, 'Islamic Bank: Concept, Precept and Prospect,' Review of Islamic Economics, 9 (2002): 29.

Muḥammad Șalāh Muḥammad al-Ṣāwī, Musykillah al-Istithmār fì al-Bunūk al-Islāmiyyah (Jeddah: Dār al-Mujtama‘, 1990).

Muhammad Sholihuddin, Kamus Istilah Ekonomi, Keuangan dan Bisnis Syariah (Jakarta: PT. Gramedia Pustaka Utama, 2011).

Muhammad Sulaymān al-Asyqar et al., Buhūth Fiqhiyyah fì Qaḍāyā Iqtiṣādiyyah Mu 'āṣirah, vol. 1 ('Ammān: Dār al-Nafā'is, 1998).

Muhammad Syafi'i Antonio, Bank Islam dari Teori ke Praktek (Jakarta: Gema Insani Press, 2011).

Muhammad Taqi Usmani, An Introduction to Islamic Finance (London: Kluwer Law International, 2002).

Muhammad Uzair, 'Some Conceptual and Practical Aspect of Interest Free Banking,' dalam Studies in Islamic Economis, ed. Khursid Ahmed (Leicester: The Islami Foundation; Jeddah: International Center for Research in Islamic Economics King Abdul Aziz University), 47.

Muhammad, Manajemen Pembiayaan Bank Syariah (Yogyakarta: Unit Penerbit dan Percetakan AMP YKPN, 2005).

Muhammad, Sistem dan Prosedur Operasional Bank Syariah (Yogyakarta: UII Press, 2000).

Nazih Kamāl Hammād, 'al-Mu'ayyidāt al-Shar'iyyah li Haml al-Madīn alMumāthīl 'alā al-Wafāwa Butlān al-Hukm bi al-Ta'wīd al-Mālī 'an Darār al-Mumāthillah,' Journal of Research in Islamic Economic, 3/1 (1985): 101-108.

Nima Mersadi Tabari, 'Islamic Finance and the Modern World: The Legal Principles Governing Islamic Finance in International Trade,' Journal Company Law, 31/8 (2010): 249-254.

Nor 'Azzah Kamri \& Fadhilah Mansor, 'Aplikasi Konsep al-Murābaḥah dalam Penawaran Instrumen di Institusi Perbankan Islam di Malaysia,' Prosiding Seminar Kewangan Islam (Kuala Lumpur: Akademi Pengajian Islam Universiti Malaya, 2002).

Nur Kholis, 'Murābahah sebagai Instrumen Pembiayaan Islam: Konsep dan Pelaksanaannya di Baitul Mal Wattamwil (BMT) Yogyakarta,' (Disertasi Sarjana, Jabatan Syariah dan Ekonomi, Akademi Pengajian Islam, Universiti Malaya, Kuala Lumpur, 2006).

Rafīq Yūnus al-Mișrī, al-Ribā wa al-Fā'idah, Dirāsah Iqtiṣādiyyah Muqāranah (Dimashq: Dār al-Fikr al-Mu'āṣir, 1999). 
Sami Hamoud, Islamic Banking (London: Arabian Information Ltd., 1985).

Shams al-Dīn al-Shaykh Muḥammad al-Dusūqī, Hāshiyah al-Dusūqī 'alā alSharh al-Kabīr, vol. 4 (Bayrūt: Dār al-Fikr, t.t.).

Sudin Haron, Prinsip dan Operasi Perbankan Islam (Kuala Lumpur: Berita Publishing Sdn. Bhd., 1996).

Taufiqul Hulam \& Muhammad Muzani, 'Penjadualan Semula Hutang Murabahah di Bank Rakyat Indonesia Syariah Cawangan Pekanbaru Berdasarkan Hukum Islam,' Jurnal Perspektif Hukum, 16/1 (2016): 6074.

Veithzal Rivai, Islamic Banking: Ekonomi Islam Bukan Opsi Tetapi Solusi (Jakarta: Bumi Aksara, 2010).

Yūsuf al-Qaraḍawī, Bay 'al-Murābahah li al- 'Āmir bi al-Shirā' kama Tajrīh̄̄ al-Mașārif al-Islāmiyyah (Maktabah Wahbah, 1987).

\section{Temu bual}

Arfan Maulana (Bahagian Pemasaran, Bank Syariah Mandiri, Cawangan Dumai, Indonesia), dalam temu bual beliau bersama penulis pada 20 Disember 2015.

M. Restu al-Fahmi (Bahagian Pemasaran Bank Syariah Mandiri, Cawangan Dumai), dalam temu bual beliau bersama penulis pada 10 Januari 2015. 
Jurnal Syariah, Jil. 26, Bil. 2 (2018) 231-262 